\title{
Solid-State Fermentation Reduces Phytic Acid Level, Improves the Profile of Myo-Inositol Phosphates and Enhances the Availability of Selected Minerals in Flaxseed Oil Cake
}

\author{
Robert Duliński ${ }^{1 *}$, Bożena Stodolak ${ }^{1}$ Łukasz Byczyński ${ }^{1}$, Aleksander Poreda ${ }^{2}$, \\ Anna Starzyńska-Janiszewska ${ }^{1}$ and Krzysztof Żyła ${ }^{1}$ \\ ${ }^{1}$ Department of Food Biotechnology, Faculty of Food Technology, University of Agriculture in Krakow, \\ ul. Balicka 122, PL-30-149 Kraków, Poland \\ ${ }^{2}$ Department of Fermentation Technology and Technical Microbiology, Faculty of Food Technology, \\ University of Agriculture in Krakow, ul. Balicka 122, PL-30-149 Kraków, Poland
}

Received: September 8, 2016

Accepted: May 4, 2017

\begin{abstract}
Summary
Flaxseed oil cake was subjected to fermentation with Rhizopus oligosporus (DSM 1964 and ATCC 64063), and the phytate ( InsP $_{6}$ ) content, myo-inositol phosphate profile and in vitro bioavailability of essential minerals were studied. Flaxseed oil cake had a phytate mass fraction of $13.9 \mathrm{mg} / \mathrm{g}$. A 96-hour fermentation of flaxseed oil cake by $R$. oligosporus DSM 1964 and R. oligosporus ATCC 64063 decreased the InsP $_{6}$ content by 48 and $33 \%$, respectively. The strains had different phytate-degrading activities: fermentation of flaxseed oil cake with $R$. oligosporus DSM 1964 was more advantageous, yielding $\operatorname{InsP}_{3-5}$ as a predominating myo-inositol compound, while fermentation with $R$. oligosporus ATCC 64603 produced predominantly $\mathrm{InsP}_{5-6}$. Solid-state fermentation of flaxseed oil cake enhanced in vitro bioavailability of calcium by 14 , magnesium by 3.3 and phosphorus by $2-4 \%$.
\end{abstract}

Key words: flaxseed oil cake, solid-state fermentation, phytates, myo-inositol phosphates, mineral availability

\section{Introduction}

Flaxseed oil cake is the solid remaining after pressing the flaxseeds to extract the oil. It is often used as a feed component due to its high nutritional value (1). However, flaxseed oil cake, especially after cold pressing, is high in soluble fibre, high-quality protein, plant lignans, minerals and polyunsaturated fatty acids and may offer benefits when used as a food additive (2). Protein isolates obtained from flaxseed oil cake have functional value (3) and prohealth and therapeutic properties (4). Flaxseed oil cake has also been used as a component of a food product ob- tained through solid-state fermentation (SSF) (5), as well as a valuable component of dough in baking bread $(6,7)$.

Despite these advantages, flaxseed by-products also contain antinutrients. Depending on the variety and growth conditions of plants, flaxseed meal contains $2.3-3.3 \%$ of phytic acid (myo-inositol-(1,2,3,4,5,6)-hexakisphosphate) (8). Phytates are the main storage forms of phosphorus in plants. A highly charged phytic acid molecule electrostatically binds minerals and proteins in complexes, decreasing their bioavailability $(9,10)$. Phytate dephosphorylation may be performed by means of thermal hydrolysis, e.g.

*Corresponding author: E-mail: r.dulinski@ur.krakow.pl

ORCID IDs: 0000-0002-0370-2556 (Duliński), 0000-0003-4333-5700 (Stodolak), 0000-0001-8221-7120 (Byczyński), 0000-0002-8255-2743

(Poreda), 0000-0003-1002-0227 (Starzyńska-Janiszewska), 0000-0002-9102-9524 (Żyła) 
during cooking, or be the result of the action of phytases. Phytases are produced endogenously in plant seeds during soaking and sprouting (11), and are also secreted by various bacteria (12) and filamentous fungi (13). Feed supplementation with phytases is a commonly used practice in the poultry nutrition and can also be applied during dough processing in wholemeal bread manufacturing $(14,15)$.

Rhizopus oligosporus has already been proven to reduce the phytate level during SSF of plant substrates (16). Rhizopus sp. are used in the production of tempeh, an Indonesian fermented food with interesting organoleptic characteristics and a high nutritional value. This kind of processing is an old and well-known treatment of soybeans, other legumes and legume-grain mixtures. It can also be applied as an alternative method for the utilisation of plant by-products. Our previous research showed that the application of R. oligosporus DSM 1964 and ATCC 64063 cultures in the processing of flaxseed oil cake may result in products with enhanced soluble phenolic content and increased antioxidant activity, suitable as functional food additives (17).

The aim of these investigations is to study the effects of fermentation of flaxseed oil cake with $R$. oligosporus DSM 1964 and ATCC 64063 strains on the content of phytates, profile of lower inositol phosphates, many of which are known for their active metabolic functions, and on the availability of essential minerals, assessed using multistep digestion in vitro procedure.

\section{Material and Methods}

The substrate for the fermentation was a cold-pressed flaxseed oil cake, supplied by the Przedsiębiorstwo Nasienne Centrala Nasienna in Sanok (Poland).

\section{Inoculum}

The spores of Rhizopus oligosporus DSM 1964 and ATCC 64063 strains (twelve-day cultures on potato extract agar slants) were harvested with sterile $0.85 \% \mathrm{NaCl}$ supplemented with $0.01 \mathrm{~g} / \mathrm{L}$ of peptone and $0.1 \mathrm{~mL} / \mathrm{L}$ of Tween 80. After filtration $(d=11 \mu \mathrm{m}$, Nylon Net Filtres; Merck Millipore, Cork, Ireland), the spore density in the suspension was measured using Thoma chamber under an optical microscope (model NK4; PZO Sp. z o.o., Warsaw, Poland).

\section{Fermentation of flaxseed oil cake}

Flaxseed oil cake (45\% moisture content, acidified to $\mathrm{pH}=4-5$ with $5 \%$, by mass per volume, lactic acid) was autoclaved at $121^{\circ} \mathrm{C}$ for $20 \mathrm{~min}$ (ELMI ESS-207; SMS Sp. z o.o., Warsaw, Poland). After sterilisation, the flaxseed oil cake was cooled to $30^{\circ} \mathrm{C}$, mixed with $R$. oligosporus inoculum $\left(3 \cdot 10^{6}\right.$ spores added to $100 \mathrm{~g}$ of raw flaxseed oil cake) and packed into Petri dishes $(d=11 \mathrm{~cm}$, three replications in each fermentation stage). Inoculated material was incubated at $37^{\circ} \mathrm{C}$ for $2 \mathrm{~h}$ (spore germination induction) followed by incubation at $30{ }^{\circ} \mathrm{C}$. The plates were removed after 48 and $96 \mathrm{~h}$ of fermentation. The fermentation was stopped by steaming $(10 \mathrm{~min})$. The lyophilised products were stored at $4{ }^{\circ} \mathrm{C}$ for later analysis. A sample of flaxseed oil cake that was prepared for fermentation, but was not inoculated, was also kept for analysis.

\section{In vitro digesting procedure}

The bioavailability of selected compounds was estimated by an in vitro method. Flaxseed oil cake samples prepared for inoculation and after 48 and $96 \mathrm{~h}$ of fermentation were treated as described by Stodolak et al. (18). Briefly, $0.5 \mathrm{~g}$ of material was mixed with $1.7 \mathrm{mg}$ of pepsin (4750 U/mg; Sigma-Aldrich, Steinheim, Germany) dissolved in $0.1 \mathrm{~mol} / \mathrm{L}$ of $\mathrm{HCl}$ and incubated at $37^{\circ} \mathrm{C}, \mathrm{pH}=2.0$, for $2 \mathrm{~h}$. Next, $2.5 \mathrm{mg}$ of pancreatin (from porcine pancreas, $8 \times$ USP (United States Pharmacopeia); Sigma-Aldrich, St. Louis, MO, USA) and $31 \mathrm{mg}$ of bile extract porcine (Sigma-Aldrich, St. Louis) dissolved in $0.1 \mathrm{~mol} / \mathrm{L}$ of $\mathrm{NaH}-$ $\mathrm{CO}_{3}$ were added. The sample was put into a dialysis tube (cellulose membrane $25 \mathrm{~mm} \times 16 \mathrm{~mm}$; Sigma-Aldrich, St. Louis) and incubated at $37^{\circ} \mathrm{C}$ for $4 \mathrm{~h}$ in $50 \mathrm{~mL}$ of imidazole buffer $(\mathrm{pH}=7.0)$. The dialysates were collected and the levels of phytate, inositol phosphates, phosphorus, myo-inositol and minerals were determined (as described below). The amounts of phytate and minerals released into the dialysate divided by their total content expressed in percentages were used as a bioavailability indicator.

\section{Determination of metal ions}

The contents of metals in the samples of fermented flaxseed oil cake and the dialysates from the in vitro procedure were determined by atomic absorption spectrometry with the flame atomisation technique (Varian AA 240FS; Agilent Technologies, Santa Clara, CA, USA), using an automatic dispensing sample system (SIPS-20; Agilent). The flows of gas (acetylene) and air were 3.5 and $14 \mathrm{~L} /$ min, respectively. Before analysis, the samples were subjected to a process of wet mineralisation, with the addition of $4 \mathrm{~mL}$ of concentrated $\mathrm{HNO}_{3}$ in sealed pressure vessels using a microwave oven Mars Xpress $\left(1200 \mathrm{~W}, 170{ }^{\circ} \mathrm{C}\right.$, 15 min; CEM Corp., Matthews, NC, USA). The elements were determined using a single sample aspiration via a rapid sequence mode (called fast sequential). Standard solutions of $\mathrm{Mg}^{2+}(100 \mathrm{mg} / \mathrm{L})$ and $\mathrm{Ca}^{2+}(40 \mathrm{mg} / \mathrm{L})$ were prepared from $1000 \mathrm{mg} / \mathrm{L}$ of stock solutions (Merck, Bilerica, MA, USA).

\section{Phosphorus determination}

The Fiske-Subbarow method (19) was used to determine phosphorus content on dry mass basis $(\mathrm{mg} / \mathrm{g})$ in dialysates and in raw samples (total content) previously mineralised in the Hach Digesdahl ${ }^{\circledR}$ digestion aparatus at $280{ }^{\circ} \mathrm{C}$ (Hach Company, Loveland, CO, USA).

\section{Determination of inositol phosphates}

Inositol phosphates were extracted from samples according to Duliński et al. (20). The profiles of the myo-inositol phosphates were determined by the analytical system using high-performance anion-exchange chromatography (HPAEC) with postcolumn derivatisation and UV/Vis detection (21). A reference sample was prepared by dissolving $2.3 \mathrm{~g}$ of sodium phytate in deionised water $(50 \mathrm{~mL})$ and adjusting the $\mathrm{pH}$ to 4.0 with $2 \mathrm{M} \mathrm{HCl}$. Next, the solution was autoclaved for $40 \mathrm{~min}$ at $121{ }^{\circ} \mathrm{C}$ under $101 \mathrm{kPa}$ 
(autoclave ELMI ESS-207; SMS Sp. z o.o.). The elution sequence of InsP $\mathrm{P}_{6-2}$ isomers was established according to the work of Blaabjerg et al. (21) mentioned above, using appropriate standard solution, sodium phytate $\left(\operatorname{Ins} \mathrm{P}_{6}\right)$, Ins $(1,2$, $4,5,6) \mathrm{P}_{5}, \operatorname{Ins}(1,4,5,6) \mathrm{P}_{4}$ Ins $(1,3,4,5) \mathrm{P}_{4}$, Ins $(1,4,5) \mathrm{P}_{3}$, Ins $(1,3,4)$ $\mathrm{P}_{3}$, and myo-inositol 2-monophosphate (all purchased from Sigma-Aldrich, Steinheim).

\section{Phytate analysis}

Ion chromatography system (Dionex UltiMate 3000) coupled with a ED50a electrochemical detector and conductivity cell (Dionex, Sunnyvale, CA, USA) was used for the analysis. Briefly, samples extracted according to Duliński et al. (20) were separated on Omnipac Pax-100 anion exchange column $(250 \mathrm{~mm} \times 4 \mathrm{~mm}$ i.d. $)$ connected in series with Omnipac Pax-100 (8 mm $\times 1 \mathrm{~mm})$ guard column (Dionex). A mobile phase using a mixture of $200 \mathrm{mM}$ sodium hydroxide (A), deionised water (B), and water-isopropanol (50:50, by volume) (C) was applied. An anion micromembrane suppressor AMMS 300 4-mm (Dionex) system was used to suppress the mobile phase conductivity before entering the conductivity cell (regenerant $0.25 \mathrm{M}$ sulfuric acid) according to Dionex Application Note 65 (22).

\section{Myo-inositol analysis}

The concentration of total and free myo-inositol in samples and in dialysates was measured by HPLC assay according to Duliński et al. (20), using Rezex ${ }^{\mathrm{TM}} \mathrm{RCM} \mathrm{Ca}{ }^{2+}$ column (375 $\mathrm{mm} \times 4 \mathrm{~mm}$ i.d., Phenomenex, Torrance, CA, USA).

\section{Statistical analysis}

Experimental data were subjected to the one-way analysis of variance (ANOVA) to detect significant differences among mean values and expressed as a mean value \pm standard deviation (S.D.). Differences among mean values were checked by the Tukey's test at $\mathrm{p}<0.05$ using Statistica for Windows, v. 12.5 (StatSoft Inc., Tulsa, OK, USA) statistical software.

\section{Results and Discussion}

\section{Profiles of phytate and inositol phosphates}

Phytate and inositol phosphates were analysed in flaxseed oil cake after 48 and $96 \mathrm{~h}$ of SSF with two different strains of $R$. oligosporus. The total phytate content on dry mass basis in flaxseed oil cake prepared for the inoculation was $13.9 \mathrm{mg} / \mathrm{g}$ (Table 1). R. oligosporus DSM 1964 decreased the phytate level to $7.8 \mathrm{mg} / \mathrm{g}$ in $48 \mathrm{~h}$ (a $44 \%$ reduction). After $96 \mathrm{~h}$, the phytate content was reduced to $7.2 \mathrm{mg} / \mathrm{g}$, but this decrease was not statistically significant. R. oligosporus ATCC 64063, on the other hand, decreased the phytate level to $9.3 \mathrm{mg} / \mathrm{g}$ after $96 \mathrm{~h}$, yielding $35 \%$ reduction. The decrease in phytate levels was similar to the $32-42 \%$ decrease reported during the fermentation of sorghum grains with lactic acid bacteria (23), but lower than the 74-89\% decrease reported during the fermentation of oat and barley grains with R. oligosporus (24).

The intermediate products of phytate degradation during the fermentation of flaxseed oil cake were: $\operatorname{Ins}(1,2,-$ $4,5,6) \mathrm{P}_{5}$, with lower amounts of Ins $(1,2,3,4,5) \mathrm{P}_{5}$, Ins $(1,2,3$,$4,6) \mathrm{P}_{5}$, Ins $(1,4,5,6) \mathrm{P}_{4}$ and Ins $(1,2,4,5) \mathrm{P}_{4}$ (B and $\mathrm{C}$ in Fig. 1$)$. The profiles indicate that the phytases of $R$. oligosporus initially removed D-3 phosphate residue from the myo-inositol ring, suggesting that they were 3-phytases (EC 3.1.3.8). However, the two $R$. oligosporus strains differed significantly in phytase activity as proven by the differences in the magnitude of InsP $_{6}$ degradation and by the spectrum of lower inositol phosphates formed. $R$. oligosporus DSM 1964 produced more $\mathrm{InsP}_{3}$ isomers, mainly Ins $(1,2,6) /(1,4,5) \mathrm{P}_{3}$ and $\operatorname{Ins}(2,4,6) \mathrm{P}_{3}$ than $R$. oligosporus ATCC 64603 did (B and $C$ in Fig. 1). The fermentation of flaxseed oil cake with $R$. oligosporus DSM 1964 produced a more advantageous profile of inositol phosphates in the products, with predominance of inositol phosphates having 3-5 phosphate moieties after $96 \mathrm{~h}$, with levels of these isomers being reasonably similar (Table 1 ). In the case of $R$. oligosporus ATCC 64603 fermentation, InsP $_{5}(18-22 \%)$ and InsP $_{1-2}(17-28 \%)$ were the dominant inositol phosphates found in the product.

Inositol triphosphates and particularly those with conserved 1,2,3 or 2,4,5 conformation of phosphate moieties are known for their antioxidant and immunostimulating effects (25). The observed changes in the profiles of inositol phosphates could therefore be applied in value-added food products based on flaxseed oil cake, since the mixtures of phytate with lower inositol phosphates have proven anticancerogenic properties (25).

\section{Mineral content}

The amount of magnesium in the initial flaxseed oil cake varied from 3.30 to $3.53 \mathrm{mg} / \mathrm{g}$; these values are comparable to those reported previously of 4.91-5.85 mg/g (6) and $5.8-6 \mathrm{mg} / \mathrm{g}(26)$. Fermentation with both R. oligosporus

Table 1. Total phytate content, profile of residual lower inositol phosphates and total myo-inositol mass fraction in flaxseed oil cake subjected to solid-state fermentation with Rhizopus oligosporus DSM 1964 and ATCC 64063 strains

\begin{tabular}{|c|c|c|c|c|c|c|c|c|c|}
\hline \multirow{2}{*}{ Sample } & \multirow{2}{*}{$\frac{t \text { (fermentation) }}{\mathrm{h}}$} & \multirow{2}{*}{$\frac{\begin{array}{c}m \text { (phytate } \\
\text { InsP }_{6} \text { ) }\end{array}}{\mathrm{mg} / \mathrm{g}}$} & \multirow{2}{*}{$\begin{array}{c}\begin{array}{c}\text { Phytate } \\
\text { reduction }\end{array} \\
\%\end{array}$} & \multicolumn{5}{|c|}{ Average relative peak area/\% } & \multirow{2}{*}{$\frac{\begin{array}{c}m(m y o-i n o s i t o l \\
\left.\text { InsP }_{0}\right)\end{array}}{\mathrm{mg} / \mathrm{g}}$} \\
\hline & & & & $\operatorname{InsP}_{6}$ & $\operatorname{InsP}_{5}$ & $\mathrm{InsP}_{4}$ & $\mathrm{InsP}_{3}$ & $\operatorname{InsP}_{2-1}$ & \\
\hline Flaxseed oil cake & 0 & $(13.9 \pm 1.9)^{\mathrm{a}}$ & 0 & 74.5 & 17.2 & 1.3 & 1.1 & 5.9 & $(6.98 \pm 0.04)$ \\
\hline \multirow[t]{2}{*}{ DSM 1964} & 48 & $(7.8 \pm 0.2)^{c}$ & -44 & 42.6 & 22.1 & 13.3 & 11.0 & 11.0 & $(6.96 \pm 0.01)$ \\
\hline & 96 & $(7.2 \pm 0.5)^{\mathrm{c}}$ & -48 & 37.8 & 17.1 & 12.0 & 18.7 & 13.7 & $(6.97 \pm 0.07)$ \\
\hline \multirow[t]{2}{*}{ ATCC 64063} & 48 & $(9.1 \pm 0.1)^{\mathrm{b}}$ & -35 & 53.7 & 22.1 & 3.4 & 4.1 & 16.7 & $(6.88 \pm 0.05)$ \\
\hline & 96 & $(9.3 \pm 0.5)^{\mathrm{b}}$ & -33 & 48.6 & 18.8 & 3.0 & 1.9 & 27.7 & $(6.84 \pm 0.04)$ \\
\hline
\end{tabular}

Values in columns are mean \pm S.D. of the sample $(N=3)$, values with different superscripts within columns are significantly different $(p<0.05)$ 


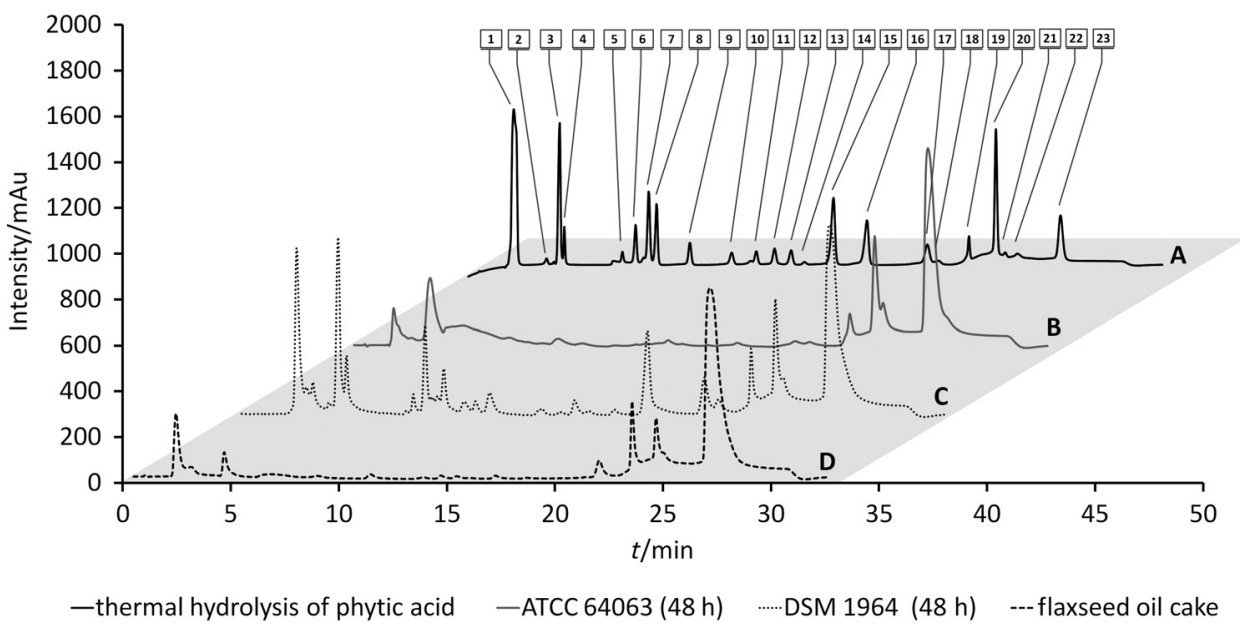

Fig. 1. Overlaid chromatograms of myo-inositol phosphate analysis in raw and fermented flaxseed oil cake after $48 \mathrm{~h}$ of fermentation. Myo-inositol phosphate in-house reference standard acquired after thermal hydrolysis of phytic acid (A), flaxseed oil cake fermented by R. oligosporus ATCC 64063 (B) and by R. oligosporus DSM 1964 (C), and raw flaxseed oil cake (D). Peaks: 1=inorganic phosphate, $2-4=\operatorname{Ins} \mathrm{P}_{1-2}, 5=\operatorname{Ins}(1,3,5) \mathrm{P}_{3}, \quad 6=\operatorname{Ins}(2,4,6) \mathrm{P}_{3}, \quad 7=\operatorname{Ins}(1,2,6) \mathrm{P}_{3}, \quad 8=\operatorname{Ins}(\mathrm{x}, \mathrm{y}, \mathrm{z}) \mathrm{P}_{3}, \quad 9=$ DL-Ins $(1,5,6) \mathrm{P}_{3}, \quad 10=$ DL-Ins $(4,5,6) \mathrm{P}_{3}, \quad 11=$ DL-Ins $(1,2,4,6) \mathrm{P}_{4}$ $12=$ DL-Ins $(1,2,-3,4) \mathrm{P}_{4}, 13=$ DL-Ins $(1,2,4,5) \mathrm{P}_{4}, \quad 14=\operatorname{Ins} \mathrm{P}_{4}, 15=$ DL-Ins $(1,2,5,6) \mathrm{P}_{4}, \quad 16=\operatorname{Ins}(2,4,5,6) \mathrm{P}_{4}, \quad 17=\operatorname{Ins}(1,4,5,6) \mathrm{P}_{4}, 18=\operatorname{Ins}(1,2,3,4,6) \mathrm{P}_{5}$, $19=\operatorname{Ins}(1,2,3,4,5) \mathrm{P}_{5}, 20=\mathrm{DL}-\operatorname{Ins}(1,2,4,5,6) \mathrm{P}_{5}, 21=\operatorname{Ins}(\mathrm{v}, \mathrm{w}, \mathrm{x}, \mathrm{y}, \mathrm{z}) \mathrm{P}_{5}, 22=\operatorname{Ins}(1,3,4,5,6) \mathrm{P}_{5}$ and $23=\operatorname{Ins}(1,2,3,4,5,6) \mathrm{P}_{6}$

strains caused a slight increase $(7 \%$ in $96 \mathrm{~h})$ of the mass fraction of $\mathrm{Mg}$ (Table 2) but did not influence significantly the contents of $\mathrm{Ca}$ and $\mathrm{P}$. The mass fraction of $\mathrm{P}$ in all test-

Table 2. The mass fractions of minerals in flaxseed oil cake before and after solid-state fermentation with Rhizopus oligosporus DSM 1964 and ATCC 64063 strains

\begin{tabular}{lccccc}
\hline \multirow{2}{*}{ Sample } & $\begin{array}{c}t \text { (fermen- } \\
\text { tation })\end{array}$ & \multicolumn{4}{c}{$w /(\mathrm{mg} / \mathrm{g})$} \\
\cline { 5 - 6 } \cline { 5 - 6 } & $\mathrm{h}$ & $\mathrm{Ca}$ & $\mathrm{Mg}$ & $\mathrm{P}$ \\
\hline $\begin{array}{l}\text { Flaxseed } \\
\text { oil cake }\end{array}$ & 0 & & $(1.01 \pm 0.07)$ & $(3.30 \pm 0.07)^{\mathrm{a}}$ & $(35.8 \pm 2.4)$ \\
\hline DSM 1964 & 48 & & $(0.96 \pm 0.04)$ & $(3.53 \pm 0.08)^{\mathrm{b}}$ & $(34.0 \pm 1.5)$ \\
& 96 & & $(1.02 \pm 0.07)$ & $(3.55 \pm 0.04)^{\mathrm{b}}$ & $(36.1 \pm 2.5)$ \\
\hline ATCC 64063 & 48 & & $(1.01 \pm 0.03)$ & $(3.45 \pm 0.11)^{\mathrm{ab}}$ & $(36.0 \pm 1.2)$ \\
& 96 & $(1.01 \pm 0.07)$ & $(3.55 \pm 0.04)^{\mathrm{b}}$ & $(35.9 \pm 2.6)$ \\
\hline Mean value & & $(1.00 \pm 0.06)$ & $(3.47 \pm 0.07)$ & $(35.5 \pm 2.0)$ \\
\hline
\end{tabular}

Values in columns are mean \pm S.D. of the sample $(N=3)$, values with different superscripts within columns are significantly different $(\mathrm{p}<0.05)$ ed samples was much higher $(34-36 \mathrm{mg} / \mathrm{g})$ than previously reported (6.43-8.24 mg/g) (6).

\section{Inositol phosphates in the dialysates after in vitro digestions}

There was a high correlation between the phytate content in the flaxseed oil cake (unfermented and fermented) and the InsP $_{6}$ level detected in dialysates obtained from the in vitro digestion $(\mathrm{R}=0.91)$. The availability of phytate in the product of the 48-hour fermentation with $R$. oligosporus was higher (33 and $34 \%$ ) than that of the control sample (28\%) (Table 3$)$. However, it was lower than the values reported for cooked buckwheat groats (39 $\%)$ and buckwheat tempeh (69-62 \%) (16) as well as for rye bread (50\%) (14). The increase of the phytate bioavailability in fermented samples could result from the metabolic activity of the mould that loosened plant tissues, which, in turn, facilitated the release (leaching) of this low-molecular compound during the in vitro digestion.

Irrespective of the sample, in vitro digestions resulted in an increase in the percentage of $\operatorname{InsP}_{3}(31-37 \%)$ in the dialysates as compared to the control $(26 \%)$ and a de-

Table 3. Effects of solid-state fermentation of flaxseed oil cake with Rhizopus oligosporus DSM 1964 and ATCC 64063 strains and in vitro simulated gastrointestinal digestion on phytate bioavailability and the profile of residual lower inositol phosphates in dialysates

\begin{tabular}{|c|c|c|c|c|c|c|c|c|c|}
\hline \multirow{3}{*}{ Sample } & \multirow{3}{*}{$\frac{t(\text { fermentation })}{\mathrm{h}}$} & \multirow{3}{*}{$\frac{w \text { (phytate) }}{\mathrm{mg} / \mathrm{g}}$} & \multirow{3}{*}{$\begin{array}{c}\begin{array}{c}\text { Phytate } \\
\text { availability }\end{array} \\
\%\end{array}$} & \multicolumn{5}{|c|}{ Average relative peak area/\% } & \multirow{3}{*}{$\begin{array}{c}\begin{array}{c}m(m y o-i n o s i t o l \\
\left.\operatorname{InsP}_{0}\right)\end{array} \\
\mathrm{mg} / \mathrm{g}\end{array}$} \\
\hline & & & & \multirow[b]{2}{*}{$\mathrm{InsP}_{6}$} & \multirow{2}{*}{$\mathrm{InsP}_{5}$} & \multirow[b]{2}{*}{$\mathrm{InsP}_{4}$} & \multirow[b]{2}{*}{$\mathrm{InsP}_{3}$} & \multirow[b]{2}{*}{ InsP $_{2-1}$} & \\
\hline & & & & & & & & & \\
\hline Flaxseed oil cake & 0 & $(3.9 \pm 0.4)^{\mathrm{a}}$ & 28 & 45.4 & 16.6 & 10.7 & 25.8 & 1.5 & n.d. \\
\hline \multirow[t]{2}{*}{ DSM 1964} & 48 & $(2.6 \pm 0.4)^{\mathrm{b}}$ & 34 & 30.1 & 18.8 & 13.3 & 32.9 & 9.6 & n.d. \\
\hline & 96 & $(2.5 \pm 0.1)^{\mathrm{b}}$ & 35 & 13.7 & 12.4 & 8.6 & 36.5 & 28.8 & n.d. \\
\hline \multirow[t]{2}{*}{ ATCC 64063} & 48 & $(3.0 \pm 0.2)^{c}$ & 33 & 29.8 & 26.9 & 7.0 & 35.1 & 2.2 & n.d. \\
\hline & 96 & $(3.5 \pm 0.1)^{\mathrm{a}}$ & 37 & 30.8 & 27.2 & 7.6 & 30.8 & 5.2 & n.d. \\
\hline
\end{tabular}

Values in columns are mean \pm S.D. of the sample $(N=3)$, values with different superscripts within columns are significantly different $(p<0.05)$ 
crease in the percentage of $\operatorname{InsP}_{5-6}$. Moreover, in the dialysate obtained from the 96-hour culture of $R$. oligosporus DSM 1964, the percentage of the InsP $P_{1-2}$ fraction was the highest $(29 \%)$, while that of the $\operatorname{InsP}_{6-5}$ fraction was the lowest $(26 \%)$.

Changes in the profiles of inositol phosphates observed after in vitro digestion could result from the residual activity of plant and mould phytases and phosphatases that acted against higher phosphorylated forms of myo-inositol in previously fermented samples. Such phosphatases could be active in both the substrate and products of the fermentation despite the high temperature treatments during processing, like autoclaving before inoculation and steaming at the end of the fermentation. Affrifah et al. (27) showed that phytases of cowpea seeds retained 95-50\% activity after steaming for 2-32 min. High thermal stability of phytases from different fungal sources was described by Simon and Igbasan (28) and Azeke et al. (29). They found that activities of purified intracellular phytases isolated from $R$. oligosporus decreased by 20 and $80 \%$ after treatment at 70 and $80{ }^{\circ} \mathrm{C}$ for $10 \mathrm{~min}$, respectively. It has been proven that phytases present in the food matrix within the tempeh structure are more heat resistant than the purified enzymes (30).

In our previous study on rye bread (20), the supplementation of dough with an exogenous phytase resulted in almost complete dephosphorylation of phytic acid. As a consequence, a release of myo-inositol into dialysates was observed during in vitro digestion. This phenomenon was not observed in the present research. Free myo-inositol was not detected in the dialysates measured by an appropriate HPLC method (Table 3).

\section{Mineral availability}

Significant differences were found in the in vitro bioavailability of $\mathrm{Ca}, \mathrm{Mg}$ and $\mathrm{P}$ in fermented and unfermented flaxseed oil cake (Table 4). Fermentation of flaxseed oil cake by R. oligosporus DSM 1964 improved the bioavailability of $\mathrm{Ca}$, on average by $15.5 \%$. This is consistent with earlier findings of many researchers concerning the preparation of dephytinised wheat (31), rye-wheat bread (32) and bread with the addition of pseudocereal grains (33), where the treatment of samples with microbial phytases increased the bioavailability of minerals, especially $\mathrm{Ca}$, $\mathrm{Zn}$ and Fe. Recent paper by Abid et al. (34) demonstrates that transgenic expression of phytase in wheat endosperm increases $\mathrm{Zn}$ and Fe bioavailability, thus enhancing its nutritional value.

It is worth stressing out that in our study the fermentation decreased the content of InsP $\mathrm{P}_{6-5}$, the compounds that have a strong capacity for chelating minerals. This effect was most evident when R. oligosporus DSM 1964 strain was used (Table 1).

The in vitro bioavailability of $\mathrm{Mg}$ also slightly increased after fermentation of flaxseed oil cake with $R$. oligosporus DSM 1964, from $9.6 \%$ in the control sample to $12.9 \%$ in fermented flaxseed oil cake (Table 4).

The in vitro bioavailability of phosphorus increased in all processed samples, with the exception of flaxseed oil cake fermented with $R$. oligosporus ATCC 64063 for $48 \mathrm{~h}$. Phosphorus bioavailability values obtained after SSF
Table 4. Effects of solid-state fermentation of flaxseed oil cake with Rhizopus oligosporus DSM 1964 and ATCC 64063 strains and in vitro simulated gastrointestinal digestion on mineral bioavailability

\begin{tabular}{lccccc}
\hline \multirow{2}{*}{ Sample } & $\begin{array}{c}\text { t(fermen- } \\
\text { tation) }\end{array}$ & & \multicolumn{3}{c}{ In vitro bioavailability/\% } \\
\cline { 2 - 3 } \cline { 5 - 6 } & $\mathrm{h}$ & $\mathrm{Ca}$ & $\mathrm{Mg}$ & $\mathrm{P}$ \\
\hline $\begin{array}{l}\text { Flaxseed } \\
\text { oil cake }\end{array}$ & 0 & & $(20.9 \pm 3.2)^{\mathrm{a}}$ & $(9.6 \pm 0.2)^{\mathrm{a}}$ & $(4.5 \pm 0.9)^{\mathrm{a}}$ \\
\hline DSM 1964 & 48 & & $(35.02 \pm 5.1)^{\mathrm{b}}$ & $(12.9 \pm 1.6)^{\mathrm{b}}$ & $(8.4 \pm 0.8)^{\mathrm{c}}$ \\
& 96 & & $(37.80 \pm 6.1)^{\mathrm{b}}$ & $(12.6 \pm 1.3)^{\mathrm{b}}$ & $(8.2 \pm 0.2)^{\mathrm{c}}$ \\
\hline ATCC 64063 & 48 & & $(28.6 \pm 7.3)^{\mathrm{ab}}$ & $(11.5 \pm 0.5)^{\mathrm{ab}}$ & $(4.2 \pm 0.3)^{\mathrm{a}}$ \\
& 96 & & $(34.0 \pm 2.2)^{\mathrm{ab}}$ & $(11.8 \pm 0.4)^{\mathrm{ab}}$ & $(6.1 \pm 0.3)^{\mathrm{b}}$ \\
\hline Mean value & & $(1.00 \pm 0.06)$ & $(3.47 \pm 0.07)$ & $(35.5 \pm 2.0)$ \\
\hline
\end{tabular}

Values in columns are mean \pm S.D. of the sample $(N=3)$, values with different superscripts within columns are significantly different $(\mathrm{p}<0.05)$

were $3.8 \%$ higher after fermentation with $R$. oligosporus DSM 1964 and $1.6 \%$ higher after fermentation with R. oligosporus ATCC 64063 than in control. The phosphorus level in dialysates from the in vitro digestion was strongly negatively correlated with total $(\mathrm{R}=-0.78)$ and dialysable $(\mathrm{R}=0.7)$ phytate contents. Thus, it can be assumed that the increase in the phosphorus bioavailability was the consequence of the release of this mineral from the phytate. The efficient hydrolysis of InsP $_{6}$ (Table 1 ) observed in our study is the result of the action of fungal phytases and phosphatases (35). The increase in phosphorus bioavailability by $4.5 \%$ was also reported for Aspergillus niger phytase added to corn-soy feed in a broiler diet (36).

\section{Conclusions}

Solid-state fermentation of flaxseed oil cake with Rhizopus oligosporus DSM 1964 strongly reduced the content of antinutritional phytate and generated a favourable profile of lower inositol phosphates, with a significant amount of inositol triphosphates that have beneficial physiological activities. The changes in the phytate level and in the profile of inositol phosphates in the fermented flaxseed oil cake were correlated with the improvement in the in vitro bioavailability of calcium, magnesium and phosphorus. In conclusion, the fermentation of flaxseed by-product with $R$. oligosporus DSM 1964 can increase its potential application as a food additive.

\section{Acknowledgements}

The authors would like to thank for the financial support from the Ministry of Science and Higher Education of Poland (grant number DS 3700/WTŻ/2015).

\section{Conflict of interest}

There were no conflicts of interest expressed by the authors. The authors confirm their responsibility for the content and writing of the paper. 


\section{References}

1. Ramachandran S, Singh SK, Larroche C, Soccol CR, Pandey A. Oil cakes and their biotechnological applications - a review. Bioresour Technol. 2007;98:2000-9. https://doi.org/10.1016/j.biortech.2006.08.002

2. Conforti FD, Davis SF. The effect of soya flour and flaxseed as a partial replacement for bread flour in yeast bread. Int J Food Sci Technol. 20 06;41:95-101. https://doi.org/10.1111/j.1365-2621.2006.01410.x

3. Mueller K, Eisner P, Yoshie-Stark Y, Nakada R, Kirchhoff E. Functional properties and chemical composition of fractionated brown and yellow linseed meal (Linum usitatissimum L.). J Food Eng. 2010;98:453-60. https://doi.org/10.1016/j.jfoodeng.2010.01.028

4. Udenigwe CC, Lu YL, Han CH, Hou WC, Aluko RE. Flaxseed protein-derived peptide fractions: antioxidant properties and inhibition of lipopolysaccharide-induced nitric oxide production in murine macrophages. Food Chem. 2009; 116:277-84.

https://doi.org/10.1016/j.foodchem.2009.02.046

5. Stodolak B, Starzyńska-Janiszewska A, Mickowska B. Effect of flaxseed oil-cake addition on the nutritional value of grass pea tempeh. Food Sci Technol Res. 2013;19:1107-14. https://doi.org/10.3136/fstr.19.1107

6. Ogunronbi O, Jooste PJ, Abu JO, Van Der Merwe B. Chemical composition, storage stability and effect of cold-pressed flaxseed oil cake inclusion on bread quality. J Food Process Preserv. 2011;35:64-79.

https://doi.org/10.1111/j.1745-4549.2009.00452.x

7. Mohamed D, Al-Okbi S, El-Hariri D, Mousa I. Potential health benefits of bread supplemented with defatted flaxseeds under dietary regimen in normal and type 2 diabetic subjects. Polish J Food Nutr Sci. 2012;62:103-8.

https://doi.org/10.2478/v10222-011-0049-x

8. Oomah BD, Kenaschuk EO, Mazza G. Phytic acid content of flaxseed as influenced by cultivar, growing season, and location. J Agric Food Chem. 1996;44:2663-6. https://doi.org/10.1021/jf9601527

9. Lopez HW, Leenhardt F, Coudray C, Remesy C. Minerals and phytic acid interactions: is it a real problem for human nutrition? Int J Food Sci Technol. 2002;37:727-39. https://doi.org/10.1046/j.1365-2621.2002.00618.x

10. Sakai H, Iwai T, Matsubara C, Usui $Y$, Okamura M, Yatou O, et al. A decrease in phytic acid content substantially affects the distribution of mineral elements within rice seeds. Plant Sci. 2015;238:170-7. https://doi.org/10.1016/j.plantsci.2015.06.006

11. Brinch-Pedersen H, Krogh Madsen C, Bæksted Holme I, Dionisio G. Increased understanding of the cereal phytase complement for better mineral bio-availability and resource management. J Cereal Sci. 2014;59:373-81. https://doi.org/10.1016/j.jcs.2013.10.003

12. Haros M, Bielecka M, Honke J, Sanz Y. Myo-inositol hexakisphosphate degradation by Bifidobacterium infantis ATCC 15697. Int J Food Microbiol. 2007;117:76-84. https://doi.org/10.1016/j.ijfoodmicro.2007.02.021

13. Rani R, Ghosh S. Production of phytase under solid-state fermentation using Rhizopus oryzae: novel strain improvement approach and studies on purification and characterization. Bioresour Technol. 2011;102:10641-9. https://doi.org/10.1016/j.biortech.2011.08.075

14. Duliński R, Cielecka EK, Pierzchalska M, Byczyński Ł, Żyła K. Profile and bioavailability analysis of myo -inositol phosphates in rye bread supplemented with phytases: a study using an in vitro method and Caco-2 monolayers. Int J Food Sci Nutr. 2016;67:454-60.

https://doi.org/10.3109/09637486.2016.1162769
15. Ismail A, Riaz M, Akhtar S, Ismail T, Ahmad Z, Ali SW. Improvement of quality attributes of bread by the application of phytases from an indigenous strain of Aspergillus niger. Pakistan J Agric Sci. 2014;51:711-8.

16. Starzyńska-Janiszewska A, Stodolak B, Duliński R, Bączkowicz M, Mickowska B, Wikiera A, Byczyński Ł. Effect of solid-state fermentation tempe type on antioxidant and nutritional parameters of buckwheat groats as compared with hydrothermal processing. J Food Process Preserv. 2016;40: 298-305. https://doi.org/10.1111/jfpp.12607

17. Stodolak B, Starzyńska-Janiszewska A, Wywrocka-Gurgul A, Wikiera A. Solid-state fermented flaxseed oil cake of improved antioxidant capacity as potential food additive. J Food Process Preserv. 2017;41:e12855. https://doi.org/10.1111/jfpp.12855

18. Stodolak B, Starzyńska-Janiszewska A, Pustkowiak H, Mickowska B. Effect of sunflower seeds addition on the nutritional value of grass pea tempeh. Pol J Food Nutr Sci. 2009;59: 145-50.

19. Fiske $\mathrm{CH}$, Subbarow Y. The colorimetric determination of phosphorus. J Biol Chem. 1925;66:375-400.

20. Duliński R, Cielecka EK, Pierzchalska M, Żyła K. Phytases improve myo-inositol bioaccessibility in rye bread: a study using an in vitro method of digestion and a Caco-2 cell culture model. Food Technol Biotechnol. 2015;53:66-72. https://doi.org/10.17113/ftb.53.01.15.3764

21. Blaabjerg K, Hansen-Møller J, Poulsen HD. High-performance ion chromatography method for separation and quantification of inositol phosphates in diets and digesta. J Chromatogr B. 2010;878:347-54.

https://doi.org/10.1016/j.jchromb.2009.11.046

22. Analysis of inositol phosphates. Application Note 65. Sunnyvale, CA, USA: Dionex, Thermo Fisher Scientific Inc.; 2003. Available from: https://tools.thermofisher.com/content/sfs/ brochures/4663-AN65_LC_insP3_2003_LPN034407-01.pdf.

23. Kruger J, Taylor JRN, Oelofse A. Effects of reducing phytate content in sorghum through genetic modification and fermentation on in vitro iron availability in whole grain porridges. Food Chem. 2012;131:220-4.

https://doi.org/10.1016/j.foodchem.2011.08.063

24. Eklund-Jonsson C, Sandberg AS, Larsson Alminger M. Reduction of phytate content while preserving minerals during whole grain cereal tempe fermentation. J Cereal Sci. 2006;44: 154-60. https://doi.org/10.1016/j.jcs.2006.05.005

25. Vucenik I, Shamsuddin AM. Cancer inhibition by inositol hexaphosphate (IP6) and inositol: from laboratory to clinic. J Nutr. 2003;113:3778S-84S.

26. Newkirk R. Flax feed industry guide. Winnipeg, Canada: Flax Canada; 2015.

27. Affrifah NS, Chinnan MS, Fang C. Modeling the thermal inactivation of phytase in steamed cowpea seeds. LWT - Food Sci Technol. 2006;39:598-604. https://doi.org/10.1016/j.lwt.2005.04.010

28. Simon O, Igbasan F. In vitro properties of phytases from various microbial origins. Int J Food Sci Technol. 2002;37: 813-22.

https://doi.org/10.1046/j.1365-2621.2002.00621.x

29. Azeke MA, Greiner R, Jany KD. Purification and characterization of two intracellular phytases from the tempeh fungus Rhizopus oligosporus. J Food Biochem. 2011;35:213-27. https://doi.org/10.1111/j.1745-4514.2010.00377.x

30. Konietzny U, Greiner R. Molecular and catalytic properties of phytate-degrading enzymes (phytases). Int J Food Sci Technol. 2002;37:791-812.

https://doi.org/10.1046/j.1365-2621.2002.00617.x 
31. Akhter S, Saeed A, Irfan M, Malik KA. In vitro dephytinization and bioavailability of essential minerals in several wheat varieties. J Cereal Sci. 2012;56:741-6. https://doi.org/10.1016/j.jcs.2012.08.017

32. García-Mantrana I, Monedero V, Haros M. Myo-inositol hexakisphosphate degradation by Bifidobacterium pseudocatenulatum ATCC 27919 improves mineral availability of high fibre rye-wheat sour bread. Food Chem. 2015;178: 267-75.

https://doi.org/10.1016/j.foodchem.2015.01.099

33. Iglesias-Puig E, Monedero V, Haros M. Bread with whole quinoa flour and bifidobacterial phytases increases dietary mineral intake and bioavailability. LWT - Food Sci Technol.
2015;60:71-7.

https://doi.org/10.1016/j.lwt.2014.09.045

34. Abid N, Khatoon A, Maqbool A, Irfan M, Bashir A, Asif I, et al. Transgenic expression of phytase in wheat endosperm increases bioavailability of iron and zinc in grains. Transgenic Res. 2017;26:109-22.

https://doi.org/10.1007/s11248-016-9983-z

35. Greiner R, Konietzny U. Phytase for food application. Food Technol Biotechnol. 2006;44:125-40.

36. Ahmad T, Rasool S, Sarwar M, Haq AU, Hasan ZU. Effect of microbial phytase produced from a fungus Aspergillus niger on bioavailability of phosphorus and calcium in broiler chickens. Anim Feed Sci Technol. 2000;83:103-14. https://doi.org/10.1016/S0377-8401(99)00122-4 